\title{
Assessment of Undiscovered Oil and Gas Resources of the West African Coastal Province, West Africa
}

The West African Coastal Province along the west African coastline recently was assessed for undiscovered, technically recoverable oil, natural gas, and natural gas liquids resources as part of the U.S. Geological Survey's (USGS) World Oil and Gas Assessment. Using a geology-based assessment methodology, the USGS estimated mean volumes of 3.2 billion barrels of oil, 23.63 trillion cubic feet of natural gas, and 721 million barrels of natural gas liquids.

\section{Introduction}

The main objective of the U.S. Geological Survey's (USGS) World Petroleum Resources Project is to assess the potential for undiscovered, technically recoverable oil and natural gas resources of the world, exclusive of the United States. As part of this program, the USGS recently completed an assessment of the West African Coastal Province (fig. 1), an area of about 202,715 square kilometers $\left(\mathrm{km}^{2}\right)$ that covers parts of Guinea, Liberia, and Sierra Leone. This assessment was based on data from oil and gas exploration wells and published geologic reports. At the time of the assessment, the province contained no discovered fields and only 10 exploration wells had been drilled - and it is considered to be underexplored for its size.

The West African Coastal Province developed in two phases: (1) the syn-rift phase was initiated during the Early Cretaceous and resulted in the formation of deep grabens and

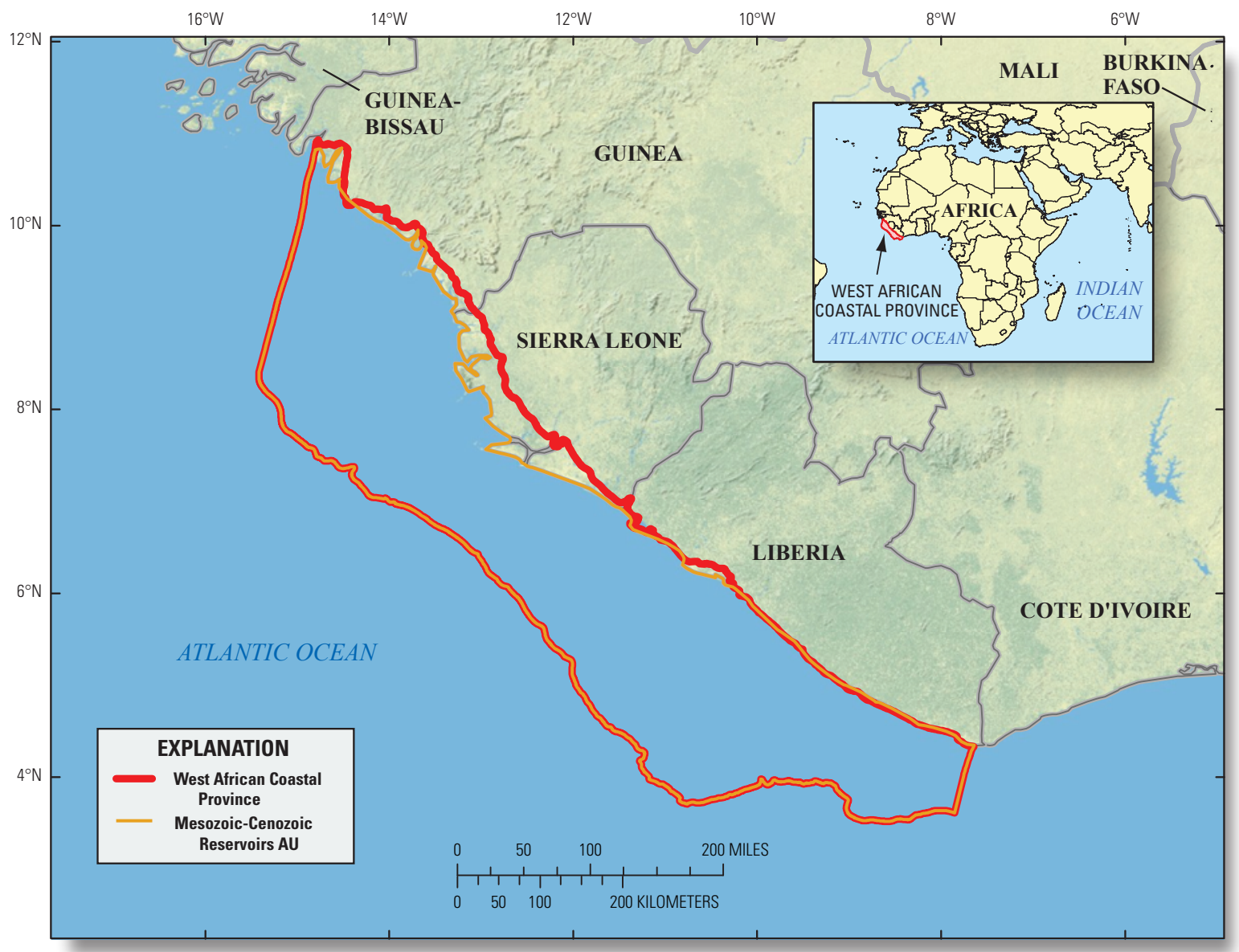

Figure 1. Locations of the West African Coastal Province and MesozoicCenozoic Reservoirs Assessment Unit $(A U)$, west Africa. 
Table 1. West African Coastal Province assessment results for undiscovered, technically recoverable oil, gas, and natural gas liquids.

[Largest expected mean field size in million barrels of oil and billion cubic feet of gas; MMBO, million barrels of oil. BCFG, billion cubic feet of gas. MMBNGL, million barrels of natural gas liquids. Results shown are fully risked estimates. For gas accumulations, all liquids are included as natural gas liquids (NGL). Undiscovered gas resources are the sum of nonassociated and associated gas. F95 represents a 95-percent chance of at least the amount tabulated; other fractiles are defined similarly. AU, assessment unit; AU probability is the chance of at least one accumulation of minimum size within the AU. NGL, natural gas liquids. TPS, total petroleum system. Gray shading indicates not applicable]

\begin{tabular}{|c|c|c|c|c|c|c|c|c|c|c|c|c|c|c|}
\hline \multirow{3}{*}{$\begin{array}{l}\text { Province, total petroleum } \\
\text { systems (TPS) and } \\
\text { assessment units (AU) }\end{array}$} & \multirow{3}{*}{$\begin{array}{l}\text { Field } \\
\text { type }\end{array}$} & \multirow{3}{*}{$\begin{array}{l}\text { Largest } \\
\text { expected } \\
\text { mean } \\
\text { field size } \\
\end{array}$} & \multicolumn{12}{|c|}{ Total undiscovered resources } \\
\hline & & & \multicolumn{4}{|c|}{ Oil (MMBO) } & \multicolumn{4}{|c|}{ Gas (BCFG) } & \multicolumn{4}{|c|}{ NGL (MMBNGL) } \\
\hline & & & F95 & F50 & F5 & Mean & F95 & F50 & F5 & Mean & F95 & F50 & F5 & Mean \\
\hline \multicolumn{15}{|c|}{ West African Coastal Province-Cretaceous Composite TPS } \\
\hline \multirow{2}{*}{$\begin{array}{l}\text { Mesozoic-Cenozoic } \\
\text { Reservoirs AU }\end{array}$} & Oil & 783 & 801 & 2,713 & 7,305 & 3,200 & 1,047 & 3,662 & 10,847 & 4,492 & 27 & 98 & 297 & 121 \\
\hline & Gas & 4,695 & & & & & 4,862 & 16,202 & 43,437 & 19,137 & 149 & 506 & 1,374 & 600 \\
\hline $\begin{array}{l}\text { Total coventional } \\
\text { resources }\end{array}$ & & & 801 & 3,713 & 7,305 & 3,200 & 5,909 & 19,864 & 54,284 & 23,629 & 176 & 604 & 1,671 & 721 \\
\hline
\end{tabular}

half-grabens; and (2) the passive margin-transform phase began in the late Albian and continues to the present. The total thickness of the Mesozoic to Cenozoic section is about 5,000 meters (m) on the outermost part of the continental shelf and thickens to as much as $10,000 \mathrm{~m}$ in the basin depocenters.

The West African Coastal Province was assessed for the first time because of increased exploratory activity and interest in its future potential. The assessment was geology-based and used the total petroleum system (TPS) concept. The geologic elements of a TPS include hydrocarbon source rocks (source rock maturation and hydrocarbon generation and migration), reservoir rocks (quality and distribution), and traps for hydrocarbon accumulation. Using these geologic criteria, the USGS defined the Cretaceous Composite TPS with one assessment unit (AU), the Mesozoic-Cenozoic Reservoirs AU (fig. 1), encompassing about $188,550 \mathrm{~km}^{2}$, that includes the offshore parts of the province to a water depth of 4,000 m. The TPS was defined to include Cretaceous marine source rocks, including the Cenomanian-Turonian source containing Type II kerogen ranging from 3 to 10 weight percent total organic carbon. Possible lacustrine source rocks may be present in grabens that developed in the Lower Cretaceous. The AU contains Cretaceous and Paleogene clastic reservoirs and traps that mostly are associated growth-fault related structures, rotated fault blocks within the continental shelf and below the mid-Cretaceous unconformity, deep water fans, turbidite channels and sandstones, slope truncations along the present-day shelf and paleoshelf edge, and Cretaceous and Paleogene stratigraphic pinch-outs along the eastern basin margin. The primary seals are Cretaceous and Paleogene marine mudstones and shales.

Exploration wells on the continental shelf and upper slope, in water depths ranging from 100 to 470 m (IHS Energy, 2009), have demonstrated the existence of an active petroleum system containing Cretaceous marine source rocks that have produced hydrocarbons most likely since the Late Cretaceous and that the hydrocarbons have migrated into Cretaceous and Paleogene reservoirs.

\section{Resource Summary}

Using a geology-based assessment, the USGS estimated mean volumes of undiscovered, technically recoverable conventional oil and gas resources for the Mesozoic-Cenozoic Reservoirs AU in the West African Coastal Province (table 1). The mean volumes are estimated at 3,200 million barrels of oil (MMBO), 23,629 billion cubic feet of gas (BCFG), and 721 million barrels of natural gas liquids. The estimated mean size of the largest oil field that is expected to be discovered is 783 $\mathrm{MMBO}$, and the estimated mean size of the expected largest gas field is 4,695 BCFG. For this assessment, a minimum undiscovered field size of 5 million barrels of oil equivalent (MMBOE) was used. No attempt was made to estimate economically recoverable reserves.

\section{For Additional Information}

Assessment results are available at the USGS Central Energy Resources Science Center website: http://energy.cr.usgs. gov/oilgas/noga/ or contact Michael E. Brownfield, the assessing geologist (mbrownfield@usgs.gov).

\section{West African Coastal Province Assessment Team}

Michael E. Brownfield, Ronald R. Charpentier, Christopher J. Schenk, Timothy R. Klett, Troy A. Cook, and Richard M. Pollastro.

\section{Reference Cited}

IHS Energy, 2009, International petroleum exploration and production database [current through December 2009]: available from IHS Energy, 15 Inverness Way East, Englewood, Colo. 80112 USA. 